\title{
Peningkatan Berpikir Kreatif dan Hasil Belajar Peserta Didik Melalui Model Think Pair And Share pada Materi Keberagaman Masyarakat
}

\author{
Puswati \\ SMP Negeri 30 Semarang \\ Email: Puswati@gmail.com
}

\begin{abstract}
Abstrak
Telah dilakukan penelitiaan tindakan kelas di SMP 30 Semarang pada materi keberagaman masyarakat. Penelitian ini bertujuan untuk mengetahui peningkatan hasil belajar dan keaktifan siswa dengan Model Think Pair and Share. Sampel dalam penelitian yaitu kelas VII dengan jumlah 32 siswa. Pemilihan sampel dilakukan berdasarkan rendahnya kekretifan siswa dan hasil belajar yang kurang optimal. Hal ini dipertegas dengan nilai rata-rata yang diperoleh siswa yang sangat jauh dari kriteria nilai yang sudah ditetapkan (KKM). Berdasarkan analisis nilai ulangan harian reratanya hanya 60 sedangkan ketuntasan belajar secara klasikal hanya mencapai 18,4\%. Penelitian ini menemukan 3 temuan yaitu pertama, pembelajaran dengan Model Think Pair and Share dapat meningkatkan hasil belajar dan kreatifitas peserta didik selama dua siklus penelitian. Kedua, peningkatan hasil belajar peserta didik yaitu pada siklus I sebesar dengan rata-rata 80.3 menjadi 86.9. Sedangkan kentuntasan klasikalnya naik sebesar $6 \%$ yaitu $87.5 \%$ pada siklus menjadi $93.5 \%$ pada siklus 2 . Ketiga, peningkatan kekreatifitas siswa terdapat sebesar $8.75 \%$ yaitu dari $73.75 \%$ pada siklus 1 menjadi $82.5 \%$ pada siklus 2 . Pembejaran Model Think Pair and Share bisa digunakan sebagai media alternatif dalam pelajaran PPKn. Hal ini juga bisa diterapkan pada mata pelajaran lainnya juga.
\end{abstract}

Kata Kunci : model Think Pair and Share, kreatifitas siswa, hasil belajar

\section{Abstract}

Research on classroom action at SMP 30 Semarang has been carried out on the material diversity of society. This study aims to determine the increase in learning outcomes and student activeness with the Think Pair and Share Model. The sample in the study was class VII with a total of 32 students. The sample selection was carried out based on the low creativity of the students and the less than optimal learning outcomes. This is confirmed by the average score obtained by students which is very far from the predetermined value criteria (KKM). Based on the analysis, the average daily test score was only 60 while the classical learning completeness only reached $18.4 \%$. This study found 3 findings: first, learning with the Think Pair and Share Model can improve learning outcomes and student creativity during the two research cycles. Second, the increase in student learning outcomes, namely in the first cycle of an average of 80.3 to 86.9 . While classical completeness increased by $6 \%$, namely $87.5 \%$ in cycle to $93.5 \%$ in cycle 2 . Third, the increase in student creativity was $8.75 \%$, from $73.75 \%$ in cycle 1 to $82.5 \%$ in cycle 2. Think Pair and Share Model chasing can be used as an alternative media in PPKn lessons. This also applies to other subjects as well.

Keywords: Think Pair and Share model, student creativity, learning outcomes

\section{PENDAHULUAN}

Pembelajaran PPKn yang selama ini terkesan hanya melibatkan proses pemindahan ilmu dari guru kepada peserta didik semata, perlu diminimalisir. Peserta didik hendaknya dilibatkan secara aktif dalam pembelajaran membina konsep dan pengetahuan yang berhubungan dengan setiap isi pelajaran yang dipelajari. Peserta didik perlu menata nalarnya, membentuk kepribadiannya, serta dapat menggunakan atau menerapkan dalam kehidupan sehari-hari. 
Perubahan cara dan sistem dalam proses pembelajaran di sekolah akan berpengaruh terhadap sikap dan kebiasaan belajar peserta didik. Ada sikap peserta didik yang pasif di dalam proses pembelajaran disebabkan model yang digunakan guru adalah model konvensional dan sikap guru yang masih kurang memperhatikan aktivitas peserta didik. Oleh karena itu, perlu ada upaya guru untuk peningkatan kreativitas peserta didik dengan menerapkan model pembelajaran yang menarik.

Apabila kesadaran belajar peserta didik dan interaksi peserta didik masih kurang serta pembelajaran guru yang monoton tanpa variasi dan inovasi yang menarik serta menyenangkan, sebagai implikasinya keaktifan peserta didik dalam kegiatan pembelajaran menjadi tidak optimal bahkan kurang. Hal ini sangat jelas berpengaruh terhadap terhadap hasil belajar peserta didik, karena tanpa keterlibatan aktif peserta didik yang optimal baik fisik maupun emosional, maka tujuan pembelajaran akan sulit dicapai sehingga hasil belajar rendah. Hal ini dipertegas dengan nilai rata-rata yang diperoleh siswa kelas VII A pada kompetensi tersebut adalah sangat jauh dari kriteria nilai yang sudah ditetapkan (KKM). Berdasarkan analisis nilai ulangan harian reratanya hanya 60 sedangkan ketuntasan belajar secara klasikal hanya mencapai $18.4 \%$. Berdasarkan hasil pengamatan guru peserta didik terlihat kurang terlibat aktif dalam pembelajaran.

Pada kegiatan belajar mengajar untuk mapel PPKn di kelas VII A peserta didik sangat kurang dalam memberikan tanggapan, bertanya, menjawab peratanyaan dari guru maupun pertanyaan dari temannya. Tidak ada yang menanggapi bila guru menayangkan sebuah gambar, vidio, dan penjelasan materi. Berdasarkan lembar observasi keaktifan siswa, nilai indeks yang didapatkan dari perhitungan adalah 50\%, dapat disimpulkan bahwa responden masih sangat rendah (tidak pernah) berpikir kreatif dalam pembelajaran.

Dari latar belakang diatas, peneliti mengidentifikasi masalah dalam penelitian ini ada dua:

1. Bagaimana meningkatkan berpikir kreatif peserta didik melalui model Think Pair And Share pada materi keberagaman masyarakat di kelas VII A SMPN 30 Semarang tahun pelajaran 2019/2020?

2. Bagaimana hasil belajar pesserta didik melalui model Think Pair And Share pada materi keberagaman masyarakat di kelas VII A SMPN 30 Semarang tahun pelajaran 2019/2020?

\section{KAJIAN TEORI}

Menurut Pribadi, B.A (2009:48) hasil belajar yang dicapai oleh siswa dapat dinilai dengan menggunakan tes dan penilaian. Sedangkan berpikir kreatif melibatkan menciptakan sesuatu yang baru atau asli. Tujuan dari berpikir kreatif adalah untuk merangsang keingintahuan dan merangsang berpikir divergen. Menurut Santrock (dalam Atik Kurniawati, 2017), kreatifitas ialah kemampuan berpikir tentang sesuatu dengan cara baru dan tidak biasa dan menghasilkan solusi yang unik atas suatu masalah.

Ada beberapa metode yang bisa digunakan peneliti dalam pembelajaran bahasa PPKn. Salah satunya yaitu model pembelajaran Think Pair and Share. Pembelajaran Think Pair and Share merupakan model pembelajaran kooperati dengan pendekatan structural (PS). Pendekatan ini memberi 
penekanan pada penggunaan struktur tertentu yang dirancang untuk mempengaruhi pola interaksi pesrta didik. Pembelajaran Think Pair and Share pertama kali dikenalkan oleh Profesor Frank Lyman dari University of Maryland (1981). Think Pair and Share memiliki prosedur yang diterapkan secara eksplisit untuk memberi peserta didik waktu lebih banyak untuk berfikir, menjawab, dan saling membantu satu sama lain. Teknik belajar mengajar Think Pair and Share sebagai sruktur kegiatan gotong royong memberi kesempatan peserta didik untuk bekerja sendiri serta bekerja sama dalam kelompok (Peni:2011).

Metode Think Pair and Share merupakan pendekatan yang dapat membantu siswa dalam pembelajaran PPKn pada materi keberagaman manusia. Dengan pendekatan ini siswa yang asalnya pasif akan menjadi aktif karena keterlibatan siswa dalam proses belajar sehingga cara berfikir kreatif siswa meningkat.

Secara skematis, hipotesa penelitian ini dapat digambarkan pada gambar sebagai berikut:

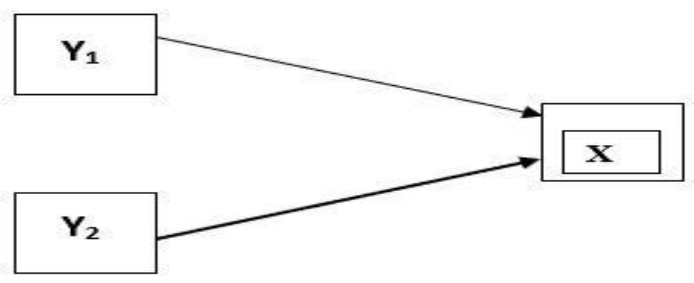

Gambar 1. Uji Hipotesis Penelitian

Keterangan;

$\mathrm{Y}_{1} \quad$ : berfikir kreatif peserta didik

$\mathrm{Y}_{2} \quad$ : hasil belajar peserta didik

$\mathrm{X} \quad$ : metode Think Pair and Share

\section{METODE PENELITIAN}

Metode penelitian ini yaitu penelitian kualitatif dengan metode perhitungan statistik. Perhitungan statistik ini dengan cara menganalisis hasil tes dan hasil observasi keaktifan siswa.

Sumber data penelitian terdiri dari data primer dan data sekunder. Data primer berasal dari data yang dikumpulkan melalui tes dan lembar observasi sedangkan data sekunder berkaitan dengan literatur, buku, laporan, informasi-infografi, gambar/foto, dokumen/file (soft/hard data).

Tabel 1. Tahapan dalam Penelitian Tindakan Kelas

\begin{tabular}{|l|l|}
\hline \multicolumn{1}{|c|}{ Tahapan } & \multicolumn{1}{c|}{ Kegiatan } \\
\hline Perencanaan Tindakan & Penyusunan RPP \\
\hline Implemetasi tindakan & Penerapan Think Pair and Share untuk daring \\
\hline Observasi & Observasi berfikir kreatif dan hasil belajar siswa \\
\hline Refleksi & Meninau hasil tindakan dan observasi \\
\hline
\end{tabular}




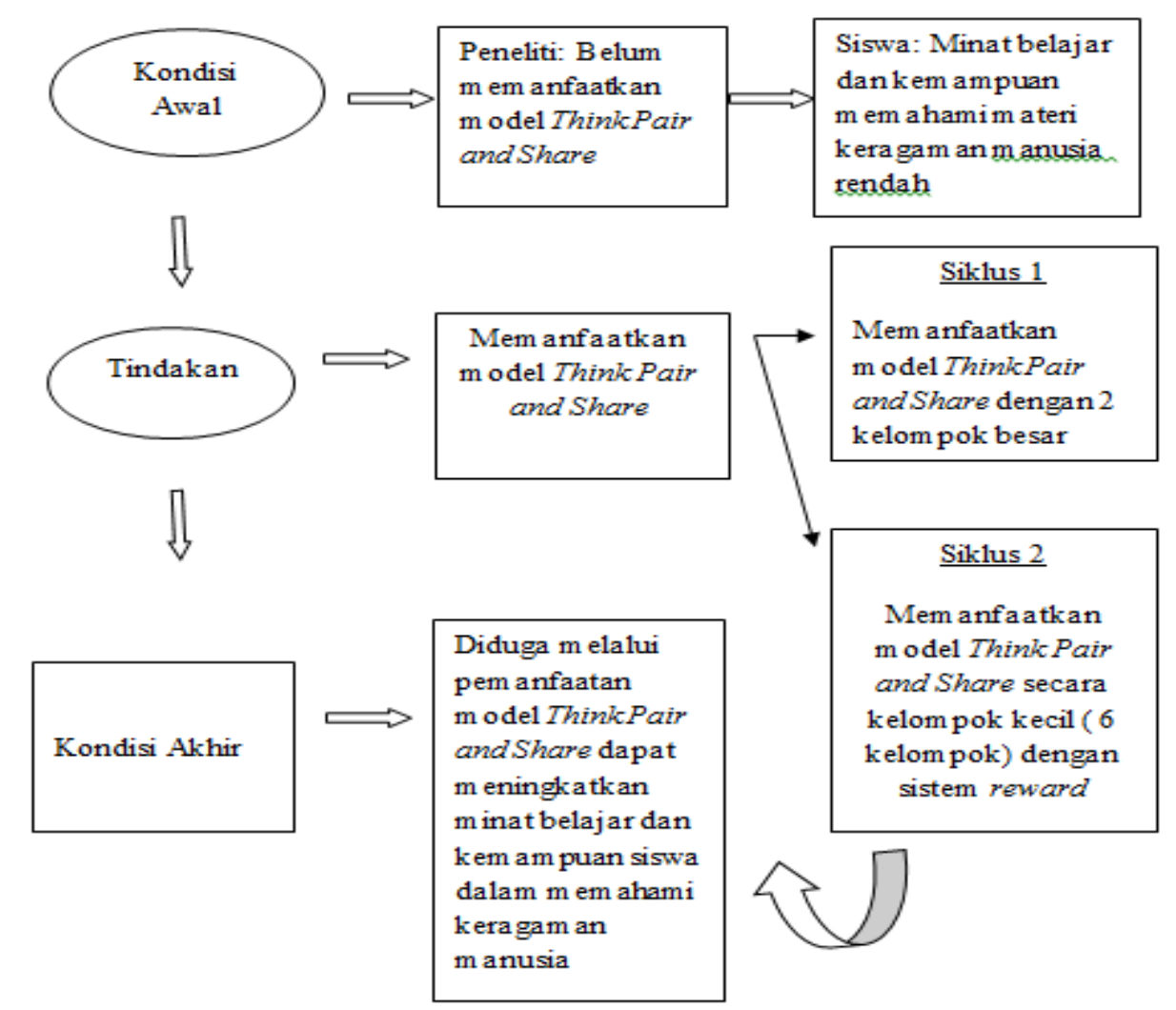

Gambar 1. Prosedur Penelitian Tindakan Kelas

Adapun pemilihan sampel yaitu kelas VIII SMP 30 Semarang karena hasil belajar dan aktivitas siswa rendah. Hal ini dapat dilihat dari sebagian besar peserta didik yang hasil belajarnya di bawah KKM.

Penelitian tindakan kelas ini dinyatakan berhasil jika ketuntasan klasikal hasil belajar minimal 85\% dan ketuntasan klasikal berfikir kreatif 75\%. Untuk pelajaran PPKn, siswa dikategorikan tuntas belajar secara perseorangan jika nilainya sama atau lebih dari KKM yaitu 75. Perhitungan ketuntasan klasikal menggunakan rumus (Trianto, 2011)

$P=\frac{f}{N} x 100 \%$

$f=$ siswa yang tuntas belajar.

$\mathrm{N}=$ jumlah total siswa.

Setelah melakukan perhitungan ketuntasan individual maupun klasikal, kemudian peneliti melakukan beberapa tahap dari penelitian tindakan kelas.

Tahapan tersebut (tersaji pada tabel 1 dan gambar 1). Setelah melalui semua tahapan tersebut, dilakukan analisis apakah terjadi peningkatan hasil belajaran. Jika terjadi peningkatan hasil belajar secara signifikan dari siklus I ke siklus selanjutnya, dan siklus selanjutnya dirasa cukup memenuhi standar ketuntasan klasikal, maka peneliti menyatakan siklus tersebut sebagai siklus terakhir. 


\section{HASIL DAN PEMBAHASAN}

\section{Pra Siklus}

Dalam penelitian tindakan kelas ini peneliti menetapkan kelas VII A SMP Negeri 30 Semarang sebagai subyek penelitian karena hasil pembelajaran di kelas VII A lebih rendah dibandingkan dengan kelas paralel lainnya. Nilai rata-rata yang diperoleh kelas VII A pada mata pelajaran PPKn hanya 69.7. Nilai tersebut masih di bawah KKM yang ditetapkan yaitu 75 dan jika dibandingkan dengan kelas setingkat paralelnya nilai tesebut adalah nilai yang paling rendah.

Rendahnya hasil pembelajaran PPKn kelas VII A terjadi karena rendahnya berpikir kreatif peserta didalam memahami materi disebabkan karena:

a. Minat peserta didik pada mata pelajaran PPKn kurang.

b. Peserta didik menganggap mata pelajaran PPKn tidak penting.

c. Peserta didik merasa proses pemelajaran PPKn kurang menarik.

d. Metode pembelajaran yang digunakan guru kurang bervariasi.

e. Proses pembelajarannya masih terpussat pada guru.

f. Proses pembelajaran cenderung mengejar materi pembelajarandengan mengesampingkan penguasaan konsep pada diri peserta didik.

g. Pengalaman belajaryang diberikan guru kurang memberikan kesan pada peserta didik.

Dari hasil pengamatan dan wawancara maka peneliti tertantang untuk melaksanakan penelitian denga subyek kelas VII A dengan menerapkan model pembelajaran Think Pair and Share untuk meningkatkan berpikir kreatif pada pembelajaran PPKn pada kelas tersebut.

Dari hasil penilaian tes yang dilaksanakan guru ternyata hasil belajar belum memuaskan karena 32 anak yang mengikuti pembelajaran belum sepenuhnya mendapatkan nilai yang sesuai KKM pelajaran PPKn yaitu 75. Di bawah ini disajikan data hasil pembelajaran mengenai bangun ruang adalah sebagai berikut:

Tabel 1. Hasil Belajar pada Pra Siklus

\begin{tabular}{|l|l|l|l|}
\hline No & $\begin{array}{l}\text { Hasil Tes } \\
\text { Prestasi Belajar }\end{array}$ & \multicolumn{1}{|c|}{ Hasil } & $\begin{array}{c}\text { Jumlah } \\
\text { Siswa }\end{array}$ \\
\hline 1 & Nilai Tertinggi & 83 & 3 anak \\
\hline 2 & Nilai Terendah & 48 & 1 anak \\
\hline 3 & $\begin{array}{l}\text { Ketuntasan } \\
\text { Belajar }\end{array}$ & $43,75 \%$ & 14 anak \\
\hline 4 & $\begin{array}{l}\text { Belum Tuntas } \\
\text { Belajar }\end{array}$ & $56,25 \%$ & 18 anak \\
\hline 5 & Nilai rata-rata & \multicolumn{2}{|c|}{69,7} \\
\hline
\end{tabular}


Berdasarkan data pada tabel di atas menunjukkan nilai tes prestasi belajar pada kondisi awal banyak siswa yang belum tuntas belajar. Sementara yang tuntas belajar baru mencapai 14 siswa atau 43.75\%. Nilai tertinggi 83 nilai terendah 48 dengan nilai rata-rata 69,7. Dari pengamatan peneliti dan kolabolator, diperoleh data observasi berfikir kreatif sebagai berikut:

Tabel 2. Hasil Observasi Siswa pada Pra Siklus
\begin{tabular}{|c|l|c|c|}
\hline No & Berfikir Kreatif & Siswa & Total \\
\hline 1 & Kategori Selalu & 5 & 25 \\
\hline 2 & Kategori Sering & 5 & 20 \\
\hline 3 & $\begin{array}{l}\text { Kategori } \\
\text { Kadang-kadang }\end{array}$ & 5 & 15 \\
\hline 4 & Kategori Jarang & 6 & 12 \\
\hline 5 & $\begin{array}{l}\text { Kategori Tidak } \\
\text { Pernah }\end{array}$ & 11 & 11 \\
\hline & & 32 & $51.87 \%$ \\
\hline
\end{tabular}

Berdasarkan tabel di atas menunjukkan lembar observasi guru dan hasil observasi peserta didik. Pembelajaran pada pra siklus ini menunjukkan siswa belum terlibat secara menyeluruh dalam pembelajaran. Hanya beberapa siswa yang menonjol kreatif yaitu 51.87\%. Beberapa faktor yang mempengaruhi adalah belum adanya aktifitas pendahuluan yang tidak dilakukan guru.

Guru hanya menyampaikan tujuan pembelajaran dan kegiatan yang akan diikuti siswa. Sementara yang dilakukan adalah menyiapkan RPP dan mengajak siswa berdoa. Pembelajaran pada pra siklus ini menunjukkan siswa belum terlibat secara menyeluruh dalam pembelajaran atau siswa masih pasif. Siswa tidak aktif bertanya, dan atau menjawab pertanyaan guru. Bahkan rata-rata kemampuan siswa dalam mengkontruksi pengetahuannya sangat rendah. Oleh karena itu, perlu adanya perbaikan dalam pembelajaran.

\section{Siklus I}

Setelah melaksanakan pembelajaran kemudian dilakukan tes hasil belajar siswa yang disajikan dalam tabel berikut.

Tabel 3. Hasil Belajar pada Siklus 1

\begin{tabular}{|l|l|c|c|}
\hline No & $\begin{array}{c}\text { Hasil Tes } \\
\text { Prestasi } \\
\text { Belajar }\end{array}$ & Hasil & $\begin{array}{l}\text { Jumlah } \\
\text { Siswa }\end{array}$ \\
\hline 1 & Nilai Tertinggi & 96 & 1 anak \\
\hline 2 & Nilai Terendah & 53 & 1 anak \\
\hline 3 & $\begin{array}{l}\text { Ketuntasan } \\
\text { Belajar }\end{array}$ & $87.5 \%$ & 28 anak \\
\hline 4 & $\begin{array}{l}\text { Belum Tuntas } \\
\text { Belajar }\end{array}$ & $12.5 \%$ & 4 anak \\
\hline 5 & Nilai rata-rata & \multicolumn{2}{|c|}{80.3} \\
\hline
\end{tabular}

Berdasarkan data pada tabel menunjukkan nilai tes prestasi belajar pada kondisi ini ada beberapa siswa yang belum tuntas belajar. Sementara yang tuntas belajar mencapai 28 siswa atau 
87.5\%. Nilai tertinggi 96 nilai terendah 53 dengan nilai rata-rata 80.3. Dari pengamatan peneliti dan kolabolator, diperoleh data sebagai berikut

Tabel 4. Hasil Observasi Keaktivan Siswa Siklus
\begin{tabular}{|c|l|c|c|}
\hline No & Berfikir Kreatif & Siswa & Total \\
\hline 1 & Kategori Selalu & 8 & 40 \\
\hline 2 & Kategori Sering & 11 & 44 \\
\hline 3 & $\begin{array}{l}\text { Kategori } \\
\text { Kadang-kadang }\end{array}$ & 8 & 24 \\
\hline 4 & Kategori Jarang & 5 & 10 \\
\hline 5 & $\begin{array}{l}\text { Kategori Tidak } \\
\text { Pernah }\end{array}$ & 8 & 0 \\
\hline & & 32 & $73.75 \%$ \\
\hline
\end{tabular}

Berdasarkan tabel di atas menunjukkan lembar observasi guru dan hasil observasi peserta didik. Pembelajaran pada siklus 1 ini menunjukkan siswa sudah terlibat dalam pembelajaran. Hanya beberapa siswa yang menonjol kreatif yaitu $73.75 \%$. Beberapa faktor yang mempengaruhi adalah siswa sudah mengenal metode Think Pad And Share sehingga aktifitas belajar lebih kreatif. Siswa aktif bertanya, dan atau menjawab pertanyaan guru. Bahkan rata-rata kemampuan siswa dalam mengkontruksi pengetahuannya sudah bagus atau menunjukkan indikator sering kreatif. Oleh karena itu, perlu adanya perbaikan dalam pembelajaran.

\section{Siklus II}

Setelah melaksanakan pembelajaran kemudian dilakukan tes hasil belajar siswa yang diasjikan dalam tabel berikut

Tabel 5. Hasil Belajar pada Siklus II

\begin{tabular}{|l|l|c|c|}
\hline No & $\begin{array}{c}\text { Hasil Tes } \\
\text { Prestasi } \\
\text { Belajar }\end{array}$ & Hasil & $\begin{array}{l}\text { Jumlah } \\
\text { Siswa }\end{array}$ \\
\hline 1 & Nilai Tertinggi & 100 & 3 anak \\
\hline 2 & Nilai Terendah & 69 & 1 anak \\
\hline 3 & $\begin{array}{l}\text { Ketuntasan } \\
\text { Belajar }\end{array}$ & $93.5 \%$ & 30 anak \\
\hline 4 & $\begin{array}{l}\text { Belum Tuntas } \\
\text { Belajar }\end{array}$ & $6.5 \%$ & 2 anak \\
\hline 5 & Nilai rata-rata & \multicolumn{3}{|c|}{86.5} \\
\hline
\end{tabular}

Berdasarkan data pada tabel di atas menunjukkan nilai tes prestasi belajar pada kondisi ini ada beberapa siswa yang sudah tuntas belajar semua. Sementara yang tuntas belajar mencapai 30 siswa atau 93.5\%. Nilai tertinggi 100 nilai terendah 69 dengan nilai rata-rata 86.56. Dari pengamatan peneliti dan kolabolator, diperoleh data sebagai berikut

Tabel 6. Hasil Observasi Keaktifan Siswa Siklus II

\begin{tabular}{|c|l|c|c|}
\hline No & Berfikir Kreatif & Siswa & Total \\
\hline 1 & Kategori Selalu & 15 & 75 \\
\hline 2 & Kategori Sering & 8 & 32 \\
\hline 3 & $\begin{array}{l}\text { Kategori } \\
\text { Kadang-kadang }\end{array}$ & 7 & 21 \\
\hline
\end{tabular}




\begin{tabular}{|c|c|c|c|}
\hline No & Berfikir Kreatif & Siswa & Total \\
\hline 4 & Kategori Jarang & 2 & 4 \\
\hline 5 & $\begin{array}{l}\text { Kategori Tidak } \\
\text { Pernah }\end{array}$ & 0 & 0 \\
\hline & & 32 & $82,5 \%$ \\
\hline
\end{tabular}

Berdasarkan tabel di atas menunjukkan lembar observasi guru dan hasil observasi peserta didik. Pembelajaran pada siklus 2 ini menunjukkan siswa sudah aktif terlibat dalam pembelajaran yaitu $82.5 \%$.

Beberapa faktor yang mempengaruhi adalah siswa sudah mengenal metode Think Pair And Share sehingga aktifitas belajar lebih kreatif. Siswa aktif bertanya, dan atau menjawab pertanyaan guru. Bahkan rata-rata kemampuan siswa dalam mengkontruksi pengetahuannya sudah sangat bagus atau menunjukkan indikator selalu kreatif. Oleh karena itu, tidak perlu adanya perbaikan dalam pembelajaran dan dianggap siklus 2 sebagai siklus terkahir.

\section{PEMBAHASAN}

Hasil belajar siswa yaitu sesuatu pengalaman belajar yang dicapai oleh siswa yang dapat dinilai dengan menggunakan tes dan penilaian. Dalam penelitian ini, hasil belajar siswa dikur dengan menggunakan tes evaluasi yang dilakukan 3 kali yaitu pada pra-siklus, siklus 1, dan siklus 2 yang diilustrasikan dalam grafik berikut

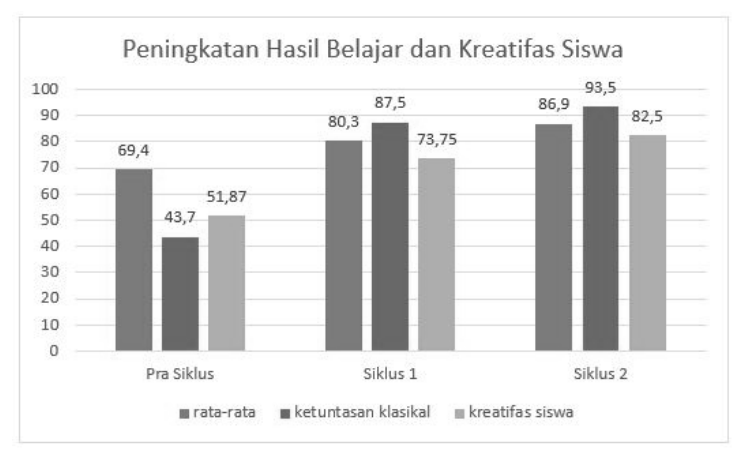

Gambar 1. Hasil belajar dan berfikir kreatif siswa

Gambar di atas menggambarkan hasil penilaian belajar peserta didik mengalami peningkatan. Hal ini sesuai dengan grafik bahwa ada peningkatan pra siklus terdapat pada siklus 1 terdapat 28 peserta didik tuntas KKM (87.5\%) dengan rata-rata 80.3. Sedangkan pasa siklus 2 terdapat 30 peserta didik tuntas KKM (93.5\%) dengan rata-rata 86.9. Artinya, pembelajaran dengan menggunakan metode Think Pair and Share berhasil meningkatkan hasil belajar siswa sebesar $6 \%$. Dengan demikian, siklus 2 dikatakan siklus akhir dalam penelitian ini karena dianggap sudah memenuhi KKM.

Kekreatifitas siswa yaitu suatu kondisi belajar mengajar yang saling memberi dan menerima antar guru dan peserta didik. Siswa yang kreatif yaitu siswa yang aktif bertanya, menjawab, dan sangat antusias terhadap penelitian ini ketika berlangsung. Hal ini dapat dilihat dari sikap antusias peserta didik mengikuti pembelajaran serta bentuk kekompakan melakukan kerjasama dalam 
menyelesaikan tugas-tugas kelompok. Peserta didik juga terlihat lebih gembira dan senang mengikuti proses pembelajaran dengan teknik ini, sehingga suasana pembelajaran lebih komunikatif, aktif dan bermakna bagi peserta didik.

Berdasarkan penelitian ini sesuai dengan grafik 1 bahwa ada peningkatan pra siklus terdapat pada siklus 1 terdapat kekreatifitas siswa sebesar 73.75\% sedangkan pada siklus 2 kekreatifitas siswa 82.5\%. Artinya, pembelajaran dengan menggunakan metode Think Pair and Share berhasil meningkatkan kekreatifitas siswa sebesar $8.75 \%$. Dengan demikian, siklus 2 dikatakan siklus akhir dalam penelitian ini karena dianggap sudah memenuhi KKM.

\section{PENUTUP}

Penggunaan teknik Menarasikan Wawancara dapat meningkatkan kemampuan berkomunikasi menulis berita mata Pelajaran Bahasa.

1. Penerapan Think Pair and Share berhasil meningkatkan hasil belajar dan kekreatifitas peserta didik di SMP 30 Semarang pada tema keberagaman.

2. Hasil penelitian memperlihatkan bahwa hasil belajar peserta didik pada siklus I sebesar dengan rata-rata 80.3 menjadi 86.9 . Sedangkan kentuntasan klasikalnya naik sebesar $6 \%$ yaitu $87.5 \%$ pada siklus 1 menjadi $93.5 \%$ pada siklus 2 .

3. Hasil observasi kekreatifitas siswa terdapat sebesar $8.75 \%$ yaitu dari $73.75 \%$ pada siklus 1 menjadi $82.5 \%$ pada siklus 2 .

\section{DAFTAR PUSTAKA}

Arianti, Peni. 2011. Pengaruh Penerapan Pembelajaran kooperatif Think Pair and Share (TPS) Terhadap Hasil Belajar Siswa SMA Negeri 8 Surakarta. http://jurnal.fkip.uns.ac.id/index.php/bio/article/.../33. (diakses 25Februari 2013)

Pribadi, B. A. 2009. Model Desain Sistem Pembelajaran. Jakarta: PT Dian Rakyat.

Santrock JW. 2017. Psikologi Pendidikan Edisi Kedua. Jakarta: Kencana Prenada Media Group.

Trianto. 2011. Model Pembelajaran Terpadu. Jakarta: Bumi Aksara. 